Global Business Research Congress, June 10-11, 2021

\title{
BOOKKEPING APPROACHES FOR CRYPTO CURRENCIES
}

\section{DOI: 10.17261/Pressacademia.2021.1428 \\ PAP- V.13-2021(27)-p.109-110}

\section{Suat Teker ${ }^{1}$, Yagmur Ergul ${ }^{2}$}

${ }^{1}$ ssik University, Departmen of Business, Sile Campus, Sile, Istanbul, Turkey. suat.teker@isikun.edu.tr, ORCID: 0000-0002-7981-3121

${ }^{1}$ Isik University, Graduate School, Maslak Campus, Sariyer, Istanbul, Turkey. ErgulYagmur@hotmail.de, ORCID: 0000-0002-5358-0913

To cite this document

Teker, S., Ergul, Y., (2021). Bookkeping approaches for crypto currencies. PressAcademia Procedia (PAP), V.13, 109-110.

Permanent link to this document: http://doi.org/10.17261/Pressacademia.2021.1428

Copyright: Published by PressAcademia and limited licensed re-use rights only.

\section{ABSTRACT}

Purpose- In the New World order, we are experiencing a period in which we meet cryptocurrencies that are physically non-existent and can be transferred without public control, without the need for intermediaries. Everything that has financial value in essence is the subject of accounting. Since crypto currencies also have a financial value, they must be recorded, accounted and taxed. This study examines how crypto assets can be defined and reflected in accounting records in accordance with the definitions.

Methodology- Since the concept of crypto money has started to enter commercial life in recent years, the literature resources are very limited, and there are many issues that have not yet become certain in terms of legislation, the approaches developed for the accounting of crypto currencies in this study are a suggestion.

Findings- In the analysis made on the basis of current literature reviews, crypto currencies can be defined as money, other liquid assets, marketable securities, inventory or other intangible assets. The accounting transactions in accordance with these definitions are explained with the help of a hypothetical example.

Conclusion- The opinion is that it would be appropriate to define crypto currencies as marketable securities in line with today's intensive usage area and acquisition purpose.

Keywords: Identification of crypto currency, accounting of crypto currency transactions, blockchain transactions, digital transactions. JEL Codes: E42, M40 M41,030

\section{REFERENCES}

Aslantaş Ateş B. (2016). Kripto Paraların Muhasebeleştirilmesi. Çankırı Karatekin Üniversitesi SBE Dergisi 7(1): $349-366$.

Bilgili F., Cengil F. M. (2019). Blockchain ve Kripto Para Hukuku. Bursa, Dora Yayınları

Çetinkaya, Ş. (2018). Kripto Paraların Gelişimi ve Para Piyasalarındaki Yerinin Swot Analizi İle İncelenmesi. Uluslararası Ekonomi ve Siyaset Bilimleri Akademik Araştırmalar Dergisi, 2(5), 11-21.

Dizkırıcı, A.S., Gökgöz A. (2018). Kripto Para Birimleri ve Türkiye'de Bitcoin Muhasebesi. Journal of Accounting Finance and Auditing Studies (JAFAS), 4(2),92- 105.

Doğan, Z., Buyrukoğlu, S., Kutbay, H. (2018). Vergi Sorunları Dergisi, 361, 23-33.

Gago U., Ağaç D. (2020). Bitcoin Kazançları Vergiye Tabi mi?. Dünya Gazetesi https://www.dunya.com/kose-yazisi/bitcoin-kazanclarivergiye-tabi-mi/488423 (Erişim Tarihi: 18.11.2020)

Grinberg, R. (2012). Bitcoin: An Innovative Alternative Digital Currency. Hastings Sci. \& Tech. L, 4, 159.

Günay, H.F., Kargı, V. (2018). Kripto Paranın Vergilendirilmesi Fikrinin Mali Yönden Değerlendirilmesi. Journal of Life Economics, 5(3), 61-76. Karaağaç Adana G., Altınırmak S.(2018). En Yüksek Piyasa Değerine Sahip On Kripto Paranın Birbirleriyle Etkileşimi. Dergipark, 6(2), 107 - 119. Kırbaş, İ. (2018). Blok Zinciri Teknoloji ve Yakın Gelecekteki Uygulama Alanları. Mehmet Akif Ersoy Üniversitesi Fen Bilimleri Enstitüsü Dergisi, 9(1), 75-82.

Kızıl C., Hanişoğlu S.G., Aslan T. (2019). Kripto Paraları Finansal Piyasalara Etkileri ve Muhasebeleştirilmesi. Bursa: Ekin Basım Yayın Dağıtım. Köylü M. K. (2018). Kripto Paralar ve Uluslararası Finansal Piyasalarda Yeri. International Journal of Academic Value Studies, 4(21), 814-821. 
Nakamoto S.(2008). Bitcoin: A Peer-to-Peer Electronic Cash System. Bitcoin.org Websitesi, https://www.bitcoin.org/bitcoin.pdf (Erişim: 25.10.2020)

Pehlivan I.(2020). Kripto Paraların Muhasebeleştirilmesi ve Raporlanması. Yüksek Lisans Tezi, Balıkkesir Üniversitesi.

Ulucan Özkul F. ve Baş E.(2020). Dijital Çağın Teknolojisi Blokzincir ve Kripto Paralar: Ulusal Mevzuat Ve Uluslararası Standartlar Çerçevesinde Mali Yönden Değerlendirme. Muhasebe ve Denetime BAKIŞ-2020, 60, 57-74.

Ulucan, Özkul F. (2020). Dijital Çağda Muhasebenin Dönüşümü: Blockchain” Teknolojisinde Muhasebe ve Mali Kontroller. Muhasebe Bilim Dünyası Dergisi, 22(2), 218-236.

Vigna P., Casey M. J. (2020). Kriptopara Çağı. Ed.Allialtıŏlu N., Güdük F. ve Şeker O. A., Ankara, Buzdağı Yayınevi.

Yükçü S. (2006). Finansal Muhasebe, İzmir, Birleşik Matbacılık.

Yüksel F.(2020). Kripto Varlıklar ve IFRS Kapsamında Kripto Paraların Muhasebeleştirilmesi. Muhasebe ve Vergi Uygulamaları Dergisi, 13(2), 429-451. 